\title{
ACRL leadership opportunities
}

\section{Your chance to get involved}

$\mathrm{N}$ ow is a good time to increase your involvement in ACRL by volunteering to serve on a division or section committee. Vice-president Betsy Wilson invites all ACRL members to contact the Appointments Committee about serving on one of ACRL's 19 committees for next year. Members may also contact one of the section vice-chairs regarding service on one of the many section committees.

Committee members help shape the organization by implementing its strategic plan (available at http://www.ala.org/acrl/ stratpla.html), reshaping the association, and influencing the direction of academic and research librarianship.

\section{You benefit by volunteering}

Volunteers not only give to the association, they get back from the association:

- Build ties with academic and research librarians around the country.

- Enhance your leadership abilities through consensus building and persuasion

- Share your expertise with colleagues.

- Gain additional expertise-learn more about a new area of academic librarianship or pick up new ideas for your current area.

\section{Appointments: The process}

Appointments are made at both the section and division levels. The ACRL vice president is responsible for the committee appointments at the division level for the year he or she serves as president. Likewise, section vice chairs are responsible for committee appointments in their respective sections the year they serve as chair. Committee slates are usually completed shortly after the Midwinter
Meeting during the year in which the individual serves as president-elect or chair-elect. The ACRL Appointments Committee assists the president-elect in this process in an advisory capacity.

\section{Factors influencing appointment}

Although the emphasis in the appointment may vary from year to year according to the prerogatives of the president-elect and section chairs, the same factors are considered. They include:

- Evidence of potential committee member's interest. Have you attended the meetings and introduced yourself to the chair? Do you have previous experience that relates to the work of the committee? Have you indicated your interest on the volunteer form?

- Demographics and composition of committee. A balance is sought with respect to type of library (community college, college, or university), geographic representation, ethnic diversity, and gencler.

- The recommendation of the current committee chair. Current committee chairs are asked to suggest potential members. AIthough all of these factors are considered, the final appointments are the prerogative of the ACRL president-elect and the section chair-elects.

\section{How to apply}

1) Select the committees that interest you. The ALA Handbook of Organization lists all of ACRL's committees and their charges. (Ed. note: The Handbook is published as a special issue of Amerncan Libraries and will automatically be mailed to all ALA members in mid-November.) Attend the committee's meetings at the Midwinter Meeting and An- 


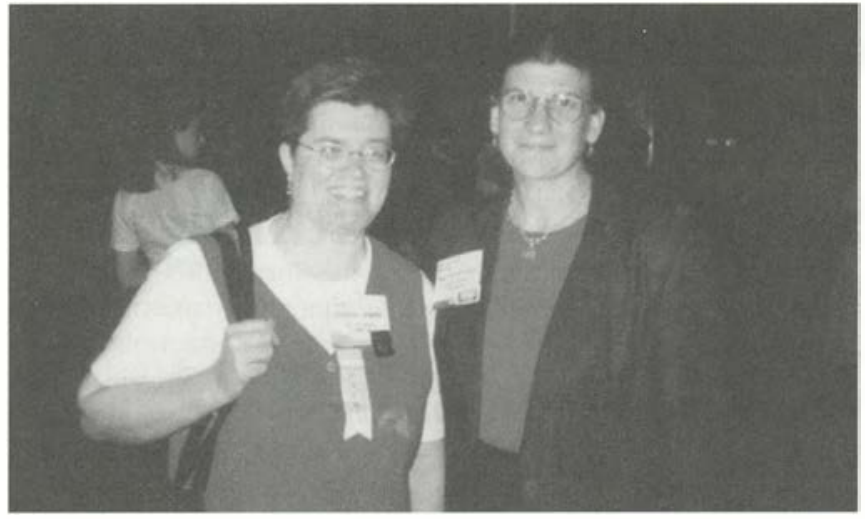

Barbara Baxter Jenkins (ACRL Board member) and Pamela Moffet Padley are both working on ACRL's 10th National Conference in Denver.

nual Conference to help you decide if those are the activities that interest you.

2) Introduce yourself. Talk with committee members. Express your interest to the committee chair. Explain how you might contribute to the work of the committee.

3) Submit a volunteer form. Complete the volunteer form included with this asticle. ( $E d$. note: This form is also available on ACRL's homepage at http://www.ala.org/ acrl.html.)

Be sure to cover all of the items asked for in the background information section of the form. If you have attended committee meetings or programs, mention that. Fill out one form for ACRL division committees and a different form for each ACRL section you volunteer to serve on a committee for. Send the ACRL committee volunteer form to Randy B. Hensley at the address on the bottom of the volunteer form; send the section volunteer forms to the appropriate section chair-elects (see list of addresses below)

4) Volunteer again ... and again. If you are not successful in being appointed one year, volunteer again the next year ... and the next. Remember that a multitude of factors-number of appointments made, number of volunteers for each committee, number of volunteers from your type of library or your geographic area-determine the actual appointment, and these factors change from year to year.

\section{ACRL section appointments}

ACRL has 17 sections (listed below). You will find a description of their areas of re- sponsibility in the $A L A$ Handbook of Organization, 1999-2000. The chair-elect of a section appoints the chair and members of all section committees. Most of these appointments are made in the spring for terms beginning immediately after the ALA Annual Conference.

If you would like to be considered for appointment as a chair or member of a section committee, fill out the ACRL Committee Volunteer Form and mail it to the chair-elect of the appropriate section listed below before December 6, 1999.

\section{African-American Studies Librarians} Section. Vice-Chair/Chair-elect: Dorothy A. Washington, Purdue University, Black Cultural Center Library. Preferred address: 3120 Eagles Way Drive, Apartment \#1534, Lafayette, IN 47905; e-mail: dawashington@hfs, purdue.edu.

\section{Anthropology and Sociology Section.} Vice-Chair/Chair-elect: Cathy L. Moore-Jansen, Social Sciences Librarian, Wichita State University, Ablah Library. Preferred address: 343 North Parkwood, Wichita, KS 67208; e-mail: moorejan@twsuvm.uc.twsu.edu.

Arts Section. Vice-Chair/Chair-elect: Lorelei A. Tanji, UCI Fine Arts Librarian, University of California-Irvine. Preferred address. P.O. Box 19557, Irvine, CA 92623-9557; e-mail: Itanji@uci.edu.

Asian, African and Middle Eastern Section. Vice-Chair/Chair-elect: Robin A. Paynter, Reference Librarian/Area Studies, University of Oregon, Eugene, OR 97403-1299; e-mail: rpaynter@oregon.uoregon.edu.

College Libraries Section. Vice-Chair/ Chair-elect: Michael Ann Zemon, Director of Libraries, Emerson College Library, 150 Beacon Street, Boston, MA 02116-1499; e-mail: ecl_maz@flo.org.

Community and Junior College Libraries Section. Vice-Chair/Chair-elect: Gregg T. 
Atkins, Library Director, College of San Mateo Library. Preferred address: 2763 Cheryl Ann Court, San Jose, CA 95124-1901; e-mail: atkins@smcccd.cc.ca.us.

Distance Learning Section. Vice-Chair/ Chair-elect: Carol Moulden, Coordinator of Off-campus Library Services, National Louis University, Wheeling Campus. Preferred address: 1935B Tanglewood Drive, Glenview, IL 60025; e-mail: cmou@wheeling1.nl.edu.

Education and Behavioral Sciences Section. Vice-Chair/Chair-elect: Lorna M. Lueck, Reference Librarian, University of California Library. Preferred address: 235 Pacific Oaks Road, \#208, Goleta, CA 93117-2935; e-mail: lueck@library.ucsb.edu.

Science and Technology Section. ViceChair/Chair-elect: Julie M. Hurd, Science Librarian, University of Illinois at Chicago, University Library. Preferred address: 1457 Ridge Ave., Evanston, IL 60201-4148; e-mail: jhurd@uic.edu.

Slavic and East European Section. ViceChair/Chair-elect: Mieczslaw (Mischa) Buczkowski, Slavic Librarian, University of Oregon, Knight Library. Preferred address: 855 Wills Ct., Eugene, OR 97405-2315; e-mail: meb@oregon.uoregon.edu.

University Libraries Section. ViceChair/Chair-elect: Elaine K. Didier, Dean, Kresge Library, Oakland University, Rochester, MI 48309-4484. Preferred address: 13060 Beacon Hill Dr., Plymouth, MI 48170-2903; email:didier@orakland. edu.

Chair/Chair-elect: William

Wortman, Miami University, Edgar W. Kind Library. Preferred address: 4879 Somerville Road, Oxford, OH 45056-9734; e-mail: wortmawa@muohio. edu.

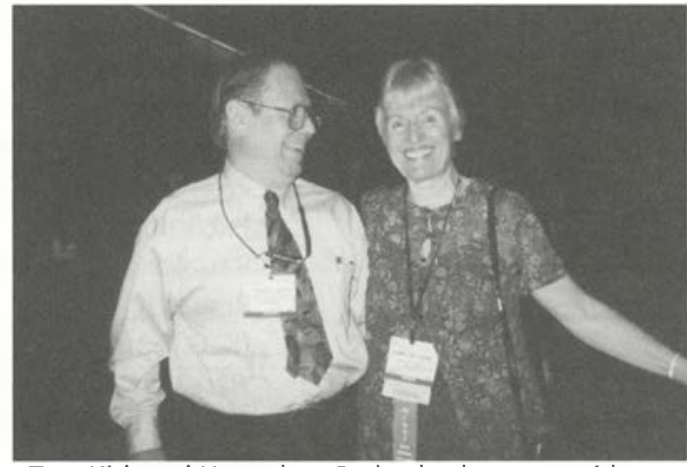

Tom Kirk and Hannelore Rader, both past presidents of $A C R L$, continue to volunteer for the association.
Western European Specialists Section. ViceChair/Chair-elect: Jeffrey Garrett, Bibl., Western Langs \& Lits, Northwestern University Library. Preferred address: 885 Pleasant Ave., Highland Park, IL 600354614; e-mail: jgarrett@nwu.edu.

Women's Studies Section. Vice-Chair/ Chair-Elect: Theresa A. Tobin, Head, Humanities \& Dewey Librarian, Massachusetts Institute of Technology (MIT). Preferred address: 104 Aldrich St., Roslindale, MA 02131-2750; e-mail: tat@mit.edu.

\section{ACRL divisional committee appointments}

ACRL has 20 standing committees to which appointments may be made for 1999-2000. A list appears on the volunteer form at the end of this article. You will find the committees listed with a description of their charges in the ALA Handbook of Organization. Appointments to ACRL standing committees are (continued on page 773) 


\section{ACRL committee volunteer form}

|

\section{Background information}

I On a separate single sheet of paper, briefly sumI marize your background and activities in the following areas: 1) ALA professional activities; 2) ACRL professional activities; 3 ) state and regional offices held and committee appointments; 4) educational background and/or other experience I that will inform the committee about special gifts and talents you would bring to the committee for which you are volunteering.

Please include in your application an expression of your professional concerns and the contribution that you can make toward strengthenI ing ACRL.

I

| Date of Application:

I Name:

Job title:

Daytime phone:

Fax number:

| E-mail address:

I Organization/library:

Institution's address:

1

| Ethnicity (optional):

\section{Division committees}

I To volunteer for a division committee, complete | this form and return it to:

\author{
Randy B. Hensley \\ University of Hawaii \\ Thomas Hale Hamilton Library \\ 2550 The Mall \\ Honolulu, HI 96822-2233 \\ phone: (808) 956-2474 \\ fax: (808) 956-5968 \\ e-mail: rhensley@hawaii.edu
}

The following division wide committees have vacancies annually. Please indicate your first three choices by marking "1," " 2 ," and " 3 " on the corresponding lines.

Budget and Finance

Bylaws

Copyright

Doctoral Dissertation Fellowship

Government Relations

Intellectual Freedom

International Relations

(Samuel) Lazerow Fellowship for Research

in Collections and Technical Services

Media Resources

Membership

Professional Development

Professional Enhancement

Publications

Racial and Ethnic Diversity

Research

(K. G.) Saur Award for Best College \&

Research Libraries article

Standards and Accreditation

Statistics

Status of Academic Librarians

I am willing to serve on any committee

for which I am qualified and needed as a regular member or as an intern.

Note: By accepting an appointment, I agree that all working papers and final products of the group are the sole property of ACRL and are not to be used for any personal projects unless written permission has been obtained from the appropriate governing body. I also certify that it does not represent a conflict of interest. I understand that failure to attend two meetings without an explanation acceptable to the chair constitutes grounds for removal.

Forms must be returned by December 6, 1999. 


\section{Section committee volunteer form}

\section{Background information for section committees}

Provide a separate sheet of information about yourself following the instructions given on the ACRL committee volunteer form (previous page) under background information. To indicate your particular interest in serving on a committee in one of ACRL's 17 sections, write the committee name(s) next to the section below.

\section{African-American Studies Librarians}

Anthropology and Sociology

Arts

Asian, African and Middle Eastern

College Libraries

Community and Junior College Libraries

Distance Learning Section

Education and Behavioral Sciences.

English and American Literature

Instruction

Law and Political Science.

Rare Books and Manuscripts

Science and Technology

Slavic and East European

University Libraries.

Western European Specialists

Women's Studies

| Date of application:

Name:

Job title:

| Daytime phone:

Fax number:

E-mail address:

\section{Returnform to:}

Return this completed form to the appropriate section vice-chair/chair-elect as indicated in the accompanying article. (Use duplicate forms if you are interested in more than one section.) You must be a member of the section to be considered for appointment.

Forms must be returned by December 6, 1999.

Membership in ALA and ACRL is required.
Organization/library:

Institution's address:

Ethnicity (optional):

Note: By accepting an appointment, I agree that all working papers and final products of the group are the sole property of ACRL and are not to be used for any personal projects unless written permission has been obtained from the appropriate governing body. I also certify that it does not represent a conflict of interest. 1 understand that failure to attend two meetings without an explanation acceptable to the chair constitutes grounds for removal.

Attendance at ALA Midwinter Meeting and Annual Conference is required. 
used as a litmus test in debates over the limitations of hate speech. In this major re-examination, Strum profiles the individuals involved, looks at the case law leading up to it, and speculates on how it might have ended differently. $\$ 25.00$. University Press of Kansas, ISBN 0-7006-0940-7.

\section{Women's Roles in Ancient Civilizations:} A Reference Guide, edited by Bella Vivante (386 pages, June 1999), is a crosscultural survey of the status of women in ancient Asia, Africa, Europe, and America from a gynocentric perspective. It highlights the ways in which women participated in and influenced their cultures' activities even when they were repressed or unacknowledged. A useful supplement to cultural histories that may omit the feminist element. \$59.95. Greenwood. ISBN 0313-30127-1.

\section{Working with Faculty to Design Under- graduate Information Literacy Programs:}

A How-to-Do-It Manual for Librarians,

by Rosemary M. Young and Stephena Harmony (123 pages, 1999), provides models for creating content and assignments for course-integrated literacy programs, standalone presentations, and full-credit courses. Evaluation instruments, technological tools, and handling administrative details are also covered. \$45.00. NealSchuman. ISBN 1-55570-354-2.

\section{World Conflicts: A Comprehensive Guide to World Strife since 1945, by Patrick Bro-} gan (682 pages, May 1999), reviews the wars, revolutions, assassinations, and terrorist attacks in a country-by-country survey of conflict in the postwar world. Brogan discusses the historical origins of the political or racial tensions, the parties involved, the main events, the outcome, and the prospects for peace. Appendices include a chronicle of terrorist events and lists of wars, coups, and assassinations up to early 1998 . $\$ 49.50$. Scarecrow. ISBN 0-8108-3551-7.

\section{("ACRL leadership . . " cont. from page 757)}

made in the spring for terms beginning immediately after the ALA Annual Conference. The Appointments Committee recommends to the president-elect of ACRL the names of members who might fill the vacancies. The president-elect makes the final appointments. If you want to be considered for an appointment to an ACRL committee, complete the form and return it to Randy B. Hensley at the address given on the form before December 6, 1999.

\section{Editorial boards}

ACRL has editorial boards for these six publications: Choice, College \& Research Libraries; College $\mathrm{E}$ Research Libraries News; New Publications; Publications in Librarianship; and Rare Books \& Manuscripts Librarianship.

Appointments to editorial boards are made at the Midwinter Meeting for terms that begin immediately after the ALA Annual Conference. The editors recommend the name of a person to fill the vacancy. The Publications Committee must approve the recommendation, and the president of ACRL makes the appointment. If you would like to be considered for appointment to an editorial board, contact the editor of the editorial board early in the fall.
Choice editor: Irving Rockwood, Choice, 100 Riverview Center, Middletown, CT 06457; e-mail: irockwood@ala-choice.org.

College \& Research Libraries editor: Donald E. Riggs, Nova Southeastern University, Fort Lauderdale, FL 33314-7796; e-mail: driggs@ nsu.acast.nova.edu.

College \& Research Libraries News editor: Mary Ellen Davis, CERL News, ACRL/ALA, 50 E. Huron St., Chicago, IL 60611-2795; e-mail: medavis@ala.org.

New publications editor: Hugh Thompson, ACRL/ALA, 50 E. Huron St., Chicago, IL 60611-2795; e-mail: hthompson@ala.org.

Publications in Librariansbip editor: John Budd, University of Missouri-Columbia School of Information Science and Learning Technologies, 217 Townsend Hall, Columbia, MO 65211; e-mail: libsjmb@showme. missouri.edu.

Rare Books \& Manuscripts Librarianship editors: Lisa M. Browar, Director, Indiana University, Lilly Library, Bloomington, IN 47405 ; lbrowar@indiana.edu; Marvin J. Taylor, Special Collections, New York University, Bobst Library, 70 Washington Square South, New York, NY 10012; taylorm@is2.nyu.edu. 